\title{
Forecasting Past and Future Trend of Physio- Chemical Parameters in Dal Lake, Srinagar Kashmir, India using Statistical Analysis and Modelling
}

\author{
Ishtiyaq Ahmad Rather, Abdul Qayoom Dar
}

\begin{abstract}
The paper presents an overview of recent physiochemical investigations on Dal lake with emphasis on lake, longterm water quality monitoring data from Lake and Water Development Authority (LAWDA1997-2017, published and unpublished data) with present analysis of Dal Lake to compare the water trends for $\mathrm{pH}$, dissolved oxygen, chemical oxygen demand(COD), $\mathrm{NO}_{3}{ }^{-} \mathrm{N}$,Total Phosphorus(TP) and Transparency. The main sampling efforts include visit to 36 samplingsitesto find the past and future trend of these physio chemicalparameters $(\mathrm{pH}$, $\mathrm{DO}, \mathrm{COD}, \mathrm{NO}_{3}{ }^{-} \mathrm{N}, \mathrm{TP}$ and Transparency).Maximum decreasing trendline was found for $\mathrm{pH}$ in Nigeen basin in summer season and lowertrends were found inNehru park basin in winter season. Maximum decreasing trendline was found for DO in Nigeen basin in summer season and lower trends were found in Nehru park basin in winter season. COD has shown maximum increasing trends in all basins mostly in Nigeen basin in summer season and lower decreasing trends in Hazratbal basin in autumn season, concentration of $\mathrm{NO}_{3}-\mathrm{N}$ and TP have shown increasing trends in all basins of lake mostly in Nigeen basin in summer season and lower increasing trends in Nehru park basin in winter season. Trend of transparency has shown decreasing trends in all basins of lake particularly in Nigeen basin in summer season and lower trends can be seen mostly in Nehru park basin in winter season. Tourism influx,maximum use of pesticides and fertilizers in the horticultureandagriculture fields during the growing season (June-August) in the Dal Lake shows a drastic change of these parameters through these years and the influx of tourists visiting this lake has increased in the summer months which isresponsible for eutrophication of Dal Lake and needs serious managerial actions.
\end{abstract}

Keywords: Dal lake, Future trend, Water quality, Eutrophication

\section{INTRODUCTION}

Generally, a lake may be defined as an enclosed water body totally surrounded by land, with no direct access to the ocean [1].Increase in anthropogenic activities on lake water systems result in high pollution loads, suchas phosphorousandnitrates etc. which cause rapid deterioration in water quality[2].Lakes are easily vulnerable to estranged inputs and relatively less dynamic and accumulate contaminants with time[3]. Information and case studies reviewed worldwide indicate that the lake water quality has been rapidly declining particularly in developing countries due to natural and anthropogenic processes including;

Revised Manuscript Received on December 30, 2019.

* Correspondence Author

Ishtiyaq Ahmad Rather*, Research Scholar, Department of Civil Engineering, National Institute of Technology Srinagar, J\&K, India, 190006 Abdul Qayoom Dar, Professor, Department of Civil Engineering, National Institute of Technology Srinagar, J\&K, India, 190006

(C) The Authors. Published by Blue Eyes Intelligence Engineering and Sciences Publication (BEIESP). This is an open access article under the CC BY-NC-ND license (http://creativecommons.org/licenses/by-nc-nd/4.0/) overexploitation, over enrichment, toxic contamination, and sedimentation [4] ,[5], [6], [7] ,[8], [9] and has caused serious adverse impacts on the structures and functions of the entire ecosystem. These entrieshave enforced future environmental and water resource experts to take necessary actions to mitigate lake and reservoir pollutions[10].The Dal Lake water which was potable in early times has been observed to deteriorate in quality very rapidly from last decades by many researchers[11],[6]reflecting anthropogenic inputs in the form of sewage from houseboats,hotels and surrounding population[12],[13],[14],[15],[16]. Periodic monitoring, analysis and prediction of water quality helps to develop management strategies to control surface-water pollution [17] This kidney-shaped lake plays a fundamental role in the cultural, economic and social dynamics of the Kashmir Valley [18] and is the only water body in India, which has been used by people living and cultivating on it for centuries [19].

\section{STUDY AREA}

The Dal Lake (Fig. 1a), is located to the NE of Srinagar city $\left(34^{\circ} 18^{\prime} \mathrm{N}\right.$ and $\left.74^{\circ} 91^{\prime} \mathrm{E}\right)$ at an altitude of $1584 \mathrm{~m}$ above mean sea level (MSL), and is the second largest fresh water lake (Jammu and Kashmir, India), comprising a myriad of interconnecting channels and is divisible into four major subbasins(Fig 1b) viz., Nigeen, Hazratbal, Nishat and Nehru park[20].Dal Lake is mainly fed by a large perennial inflow channel i.e.,Telbalnalah, which is having a sub catchment area of about $145 \mathrm{~km} 2$ and contributes about $80 \%$ of the total inflow to the lake [21],[22].The Nigeen basin (maximum depth being $6 \mathrm{~m}$ ) is the deepest basin and Nehrupark basin (maximum depth $2.5 \mathrm{~m}$ ) is the shallowest. Water from Telbal nalah and other streams enters the lake from Hazratbal basin, passes through Nishat basin, Nigeen and Nehru park basins before entering into the river Jhelum.The total water surface of the lake is $11.45 \mathrm{~km} 2$ of which $4.1 \mathrm{~km} 2$ is under floating gardens, $2.25 \mathrm{~km} 2$ under marshy conditions and $1.51 \mathrm{~km} 2$ under land [11],[23],[24].The total area of the Dal Lake catchment is about $334 \mathrm{~km} 2$, which is about twenty-eight times more than the lake area. 


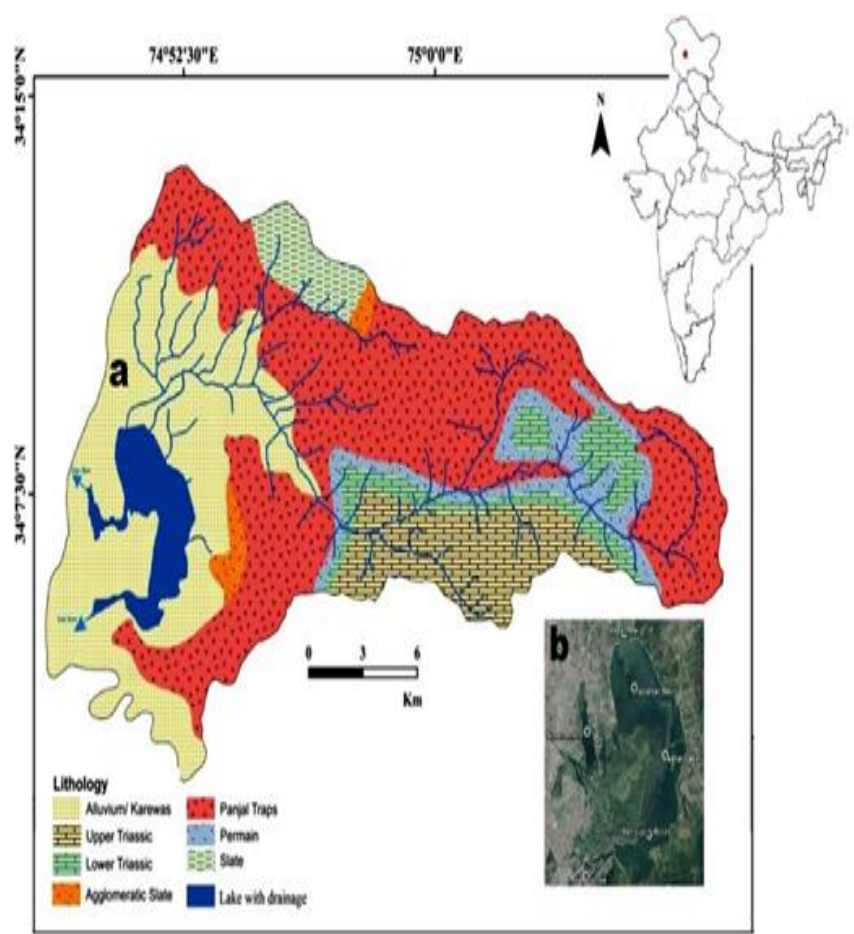

Fig. 1. Showing (a) study area and (b) basins in dal lake

\section{METHODOLOGY}

One hundred and forty-four (144) water samples were collected in (HDPE) high density polyethylene bottles from Dal Lake of Srinagar, in a grid pattern to cover the entire lake (Fig. 2) from march 2017 to January2018 in spring (Mar), summer (June), autumn(September)andwinter (January) from 36 locations.Physico-chemical parameters, such as $\mathrm{pH}$ and transparency were measured in the field by multi-parameter water quality sensor. For the analysis of dissolved oxygen (DO), chemical oxygen demand (COD), NO3-N and total phosphorus (TP), samples were taken to the Environmental Laboratory, NIT Srinagar. Water samples were analysed based on standard methods of APHA, 2005. TP and NO3-N were determined by colorimetric method.The results presented in this work are based only on physio-chemical analysis of 1-year season sampling (20172018) and were correlated with past twenty years secondary seasonal data (from "LAWDA" Lake and Water Development Authority, published and unpublished data) to find the past and future trend of these physio chemical parameters. Future prediction values were detected using trend line by means of ordinate trend value(y) from 19972030.However, there were some assumptions taken into consideration for prediction of future valuesi.e.,all the anthropogenic pressures will increase at same pace as in the decadal past, if land useland cover will remain unchanged.

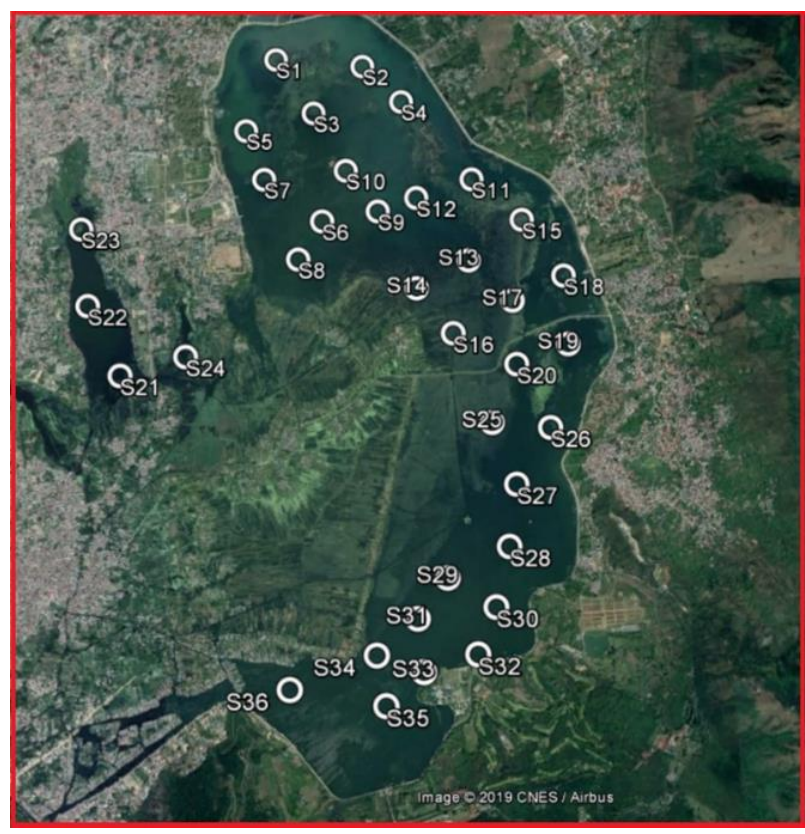

Fig. 2. showing sampling locations in Dal Lake

\section{RESULTS}

\section{A.Decadal Variation in water quality}

pH:Average annual values of $\mathrm{pH}$ ranged from 8.0 (2018) to 8.8 (1997) from last two decades. In the spring season the decadal trendlines of $\mathrm{pH}$ have decreased in all basins of lake. Maximum decreasing trendline was found for Nigeen basin $\left(\mathrm{y}=-0.0418 \mathrm{x}+8.729, \mathrm{R}^{2}=0.4963\right)$ and lower decreasing trend line was found for Nishat basin $(\mathrm{y}=-0.0049 \mathrm{x}+$ 8.0065, $\mathrm{R}^{2}=0.0182$ ). $\mathrm{pH}$ graph in spring season clearly indicates that from $1997 \mathrm{pH}$ has decreased upto10\% showing alkaline nature in all the basins from last two decades (Fig. 3a). In the summer season the decadal trendlines of $\mathrm{pH}$ have decreased in all basins of lake except Nishat basin which showed slight increasing trend.Maximum decreasing trendline was found for Nigeen basin $\left(\mathrm{y}=-0.0507 \mathrm{x}+8.9682, \mathrm{R}^{2}=0.432\right)$ and lower decreasing trend line was found for Hazratbal basin ( $\mathrm{y}=$ $\left.0.0252 \mathrm{x}+8.6896, \mathrm{R}^{2}=0.2726\right)$. $\mathrm{pH}$ graph in summer season clearly indicates that from $1997 \mathrm{pH}$ has decreased upto12\% (Fig. 3b).In the autumn season the decadal trendlines of $\mathrm{pH}$ have decreased in all basins of lake except Nishat basin which showed an increasing trend. Maximum decreasing trendline was found for Nigeen basin $(\mathrm{y}=-0.0357 \mathrm{x}+8.5537$, $\left.\mathrm{R}^{2}=0.3076\right)$ and lower decreasing trend line was found for Hazratbal basin $\left(\mathrm{y}=-0.0095 \mathrm{x}+8.28, \mathrm{R}^{2}=0.0441\right) \cdot \mathrm{pH}$ graph in autumn season(Fig.3c)clearly indicates that from $1997 \mathrm{pH}$ has decreased upto $10 \%$. In the winter season the decadal trendlines of $\mathrm{pH}$ have decreased in all basins of lake except Nishat basin which showed slight increasing trend. Maximum decreasing trendline was found for Nigeen basin ( $\left.\mathrm{y}=-0.0329 \mathrm{x}+8.471, \mathrm{R}^{2}=0.3254\right)$ and lower decreasing trend line was found for Hazratbal basin ( $\mathrm{y}=-0.0215 \mathrm{x}+$ 8.3624, $\mathrm{R}^{2}=0.1705$ ). pH graph in winter season(Fig. 3d) clearly indicates that from $1997 \mathrm{pH}$ has decreased upto $11 \%$.Overall average annual decadal values of $\mathrm{pH}$ from 1997 to 2018 shows the trend as $(y=-0.0186 x+8.3928$, $\mathrm{R}^{2}=0.4236$ ) indicating that the $\mathrm{pH}$ will further decrease to 8.0 in 2020, 7.9 in 2025 and 7.8 in 2030(Fig. 9a).

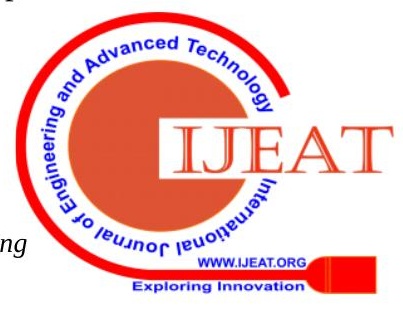




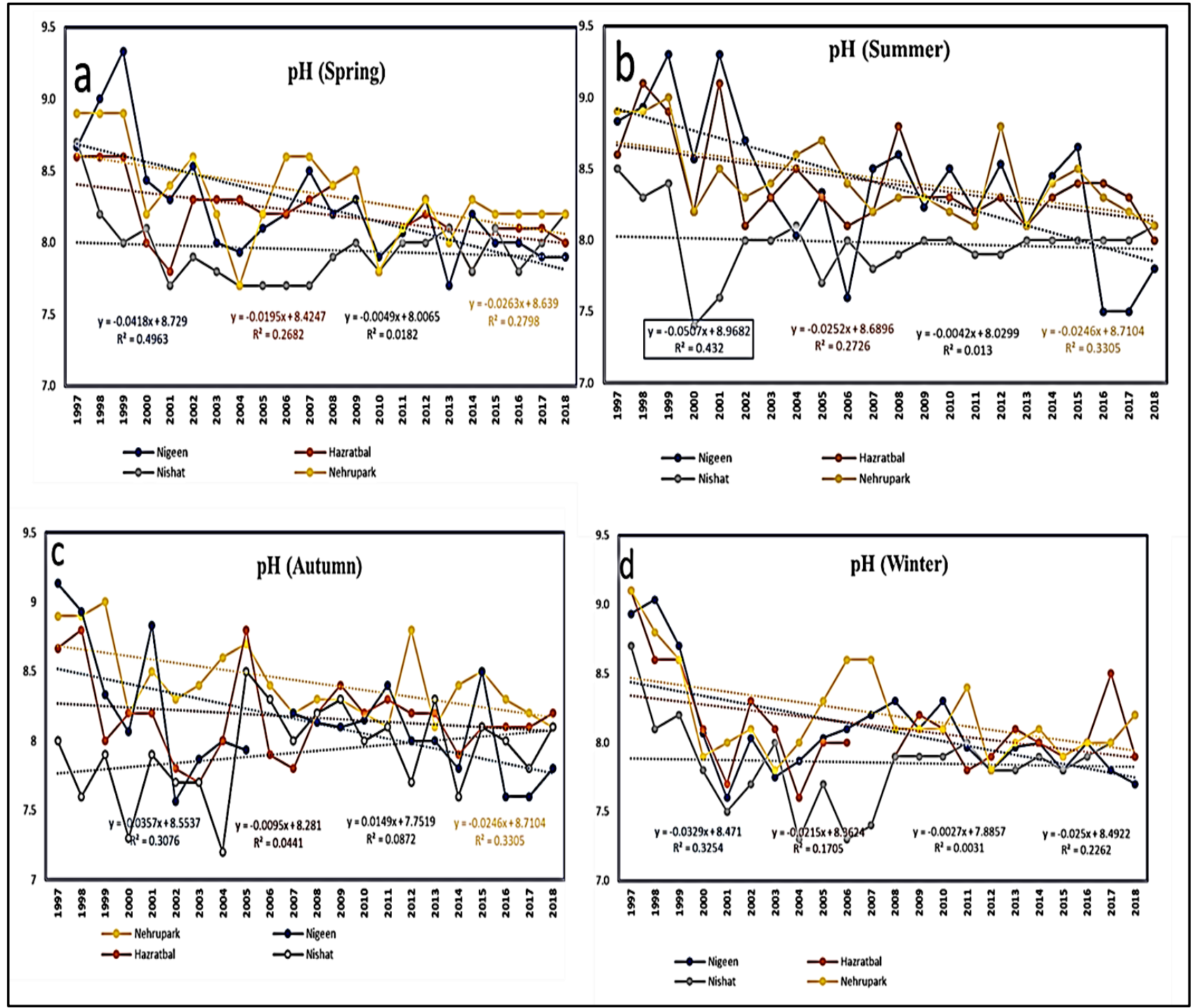

Fig. 3. showing decadal variation of pH in DalLake from 1997-2018 (a) spring (b) summer (c) autumn \and (d) winter

Dissolved oxygen (DO): Average annual values of DO ranged from $5.4 \mathrm{mg} / \mathrm{l}(2018)$ to $6.6 \mathrm{mg} / \mathrm{l}$ (1997) from last two decades. In the spring season (Fig. 4a) the decadal trendlines of DO have decreased in all basins of lake. Maximum decreasing trendline was found for Nigeen basin $\left(y=-0.1831 x+8.7064, R^{2}=0.7469\right)$ and lower decreasing trend line was found for Hazratbal basin $(\mathrm{y}=-0.0651 \mathrm{x}+$ 7.9349, $\mathrm{R}^{2}=0.1856$ ). Dissolved oxygen trendline graph in spring season clearly indicates that from 1997 DO has decreased upto 50\% showing drift in oxygen levels in all the basins from last two decades particularly in Nigeen basin.In the summer season (Fig. 4b) the decadal trendlines of DO have decreased in all basins of lake except Nishat basin which shows slight increase in oxygen levels from last one decade. Maximum decreasing trendline was found for Nigeen basin ( $\mathrm{y}=-0.1395 \mathrm{x}+7.7083, \mathrm{R} 2=0.2607)$ and lower decreasing trend line was found for Nehru park basin $(\mathrm{y}=-0.0939 \mathrm{x}+7.7512, \mathrm{R} 2=0.3237)$. Dissolved oxygen trendline graph in summer season clearly indicates that from 1997 DO has decreased upto 30\% showing drift in oxygen levels in all the basins from last two decades. In the Autumn season(Fig. 4c) the decadal trendlines of DO have decreased in all basins of lake Maximum decreasing trendline was found for Nigeen basin $\left(\mathrm{y}=-0.1821 \mathrm{x}+8.2014, \mathrm{R}^{2}=0.5568\right)$ and lower decreasing trend line was found for Nishat basin $(y=-0.0372 x+6.5192$, R2 $=0.0396)$. Dissolved oxygen trendline graph in summer season clearly indicates that from 1997 DO has decreased upto 40\% showing drift in oxygen levels in all the basins from last two decades. In the winter season(Fig. 4d) the decadal trendlines of DO have decreased in all basins of lake Maximum decreasing trendline was found for Nigeen basin $(y=-0.235 x+9.7336$, $\mathrm{R}^{2}=0.806$ ) and lower decreasing trendlinewasfoundfor Nehru parkbasin $\left(y=-0.0852 x+8.1092, \quad R^{2}=0.4492\right)$. Dissolved oxygen trendline graph in winter season clearly indicates that from 1997 DO has decreased upto 45\% showing drift in oxygen levels in all the basins from last two decades. Overall average annual decadal values of DO from 1997 to 2018 shows the trend as $\left(y=-0.1125 x+8.0012, R^{2}\right.$ $=0.762$ ) indicating that the DO will further decrease to 5.8 $\mathrm{mg} / \mathrm{l}$ in 2020, $5.2 \mathrm{mg} / \mathrm{l}$ in 2025 and $4.6 \mathrm{mg} / \mathrm{l}$ in 2030 (Fig. 9b). 


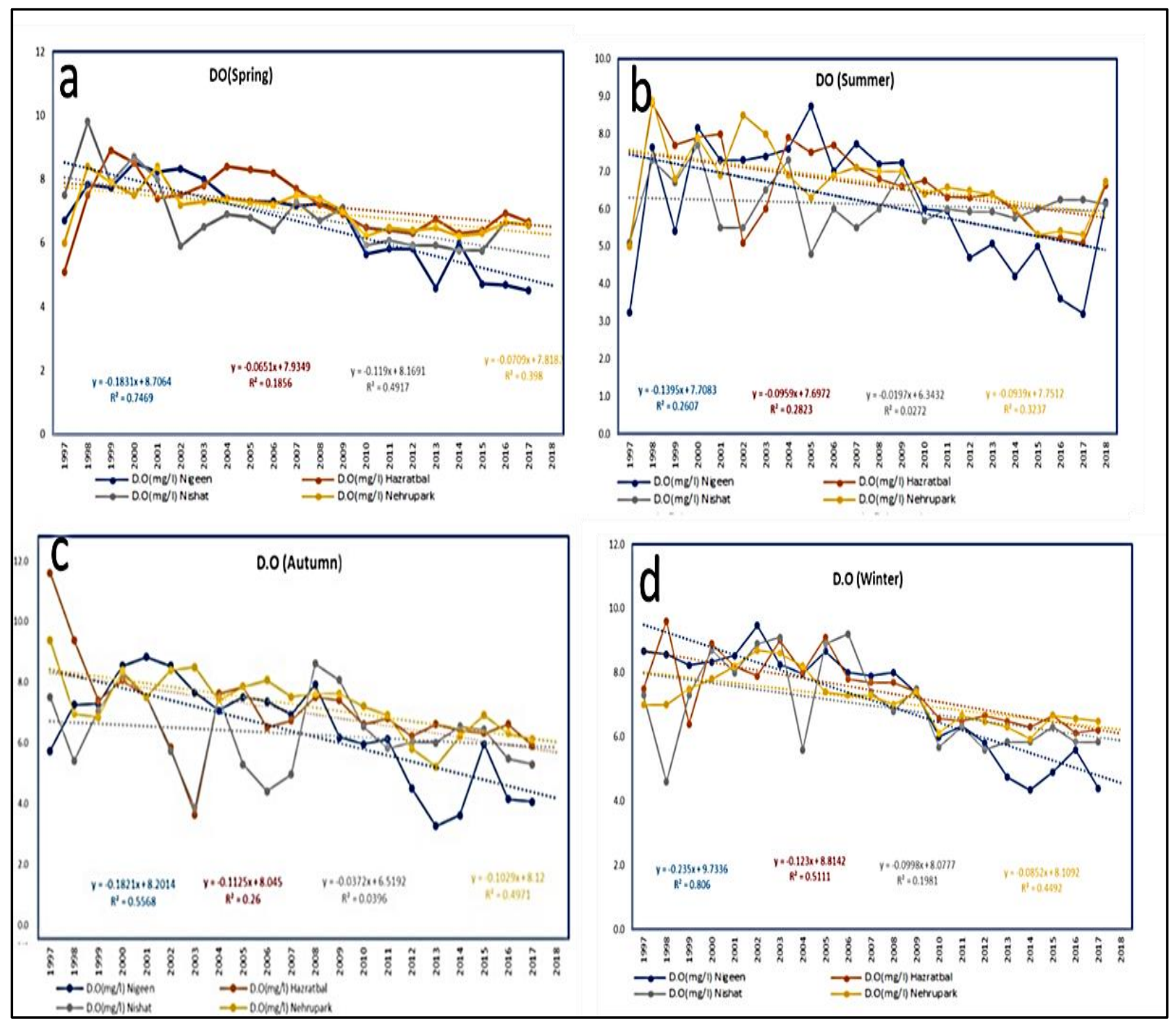

Fig. 4. showing decadal variation of DO in Dal Lake from 1997-2018 (a) spring (b) summer (c) autumn and (d) winter

Chemical oxygen demand (COD): Average annual values of COD ranged from $20.40 \mathrm{mg} / \mathrm{l}$ (1997) to $23.10 \mathrm{mg} / \mathrm{l}$ (2018) from last two decades. In the spring season the decadal trendlines of COD have increased in all basins of lake Maximum increasing trendline was found for Nigeen basin $\left(\mathrm{y}=0.7848 \mathrm{x}+11.335, \mathrm{R}^{2}=0.5066\right)$ and lower increasing trend line was found for Hazratbal basin ( $\mathrm{y}=-0.0039 \mathrm{x}+$ 20.233).COD trendline graph in spring season clearly indicates that from 1997 COD has increased upto 120\% showing higher concentration of COD in all the basins from last two decades particularly in Nigeen basin (Fig. 5a).In the summer season the decadal trendlines of COD have increased in all basins of lake Maximum increasing trendline was found for Nigeen basin $\left(\mathrm{y}=0.6368 \mathrm{x}+16.416, \mathrm{R}^{2}\right.$ $=0.1931$ ) and lower increasing trend line was found for Nishat basin $\left(\mathrm{y}=0.0481 \mathrm{x}+21.186, \mathrm{R}^{2}=0.003\right)$. COD trendline graph in summer season clearly indicates (Fig. 5b) that from 1997 COD has increased upto 100\% showing higher concentration of COD in all the basins. In the autumn season decadal trendlines of COD have increased in all basins oflake. Maximum increasing trendline was found for Nishat basin $\left(\mathrm{y}=0.4416 \mathrm{x}+19.714, \mathrm{R}^{2}=0.2141\right)$ and lower increasing trend line was found for Hazratbal basin $(\mathrm{y}=$ $\left.0.0273 x+26.014, \mathrm{R}^{2}=0.0006\right)$. COD trendline graph in autumn season (Fig. 5c) clearly indicates that from 1997 COD has increased upto 50\% showing higher concentration of COD in all the basins from last two decades particularly in Nishat basin. In the winter season the decadal trendlines of COD have increased in all basins of lake. Maximum increasing trendline was found for Nigeen basin ( $\mathrm{y}=$ $\left.0.5771 \mathrm{x}+16.875, \mathrm{R}^{2}=0.2983\right)$ and lower increasing trend line was found for Nehru park basin $(y=0.0688 \mathrm{x}+18.767$, $\left.\mathrm{R}^{2}=0.0054\right)$. COD trendline graph in winter season clearly indicates that from 1997 COD has increased upto 75\% showing higher concentration of COD in all the basins from last two decades particularly in Nigeen basin. (Fig. 5d). Overall average annual decadal values of COD from 1997 to 2018 shows trend as $\left(\mathrm{y}=0.1552 \mathrm{x}+20.356, \mathrm{R}^{2}=0.0716\right)$ indicating that the COD will further increase to $23.5 \mathrm{mg} / \mathrm{l}$ in 2020, $24.20 \mathrm{mg} / \mathrm{l}$ in 2025 and $25 \mathrm{mg} / \mathrm{l}$ in 2030(Fig. 9c). 


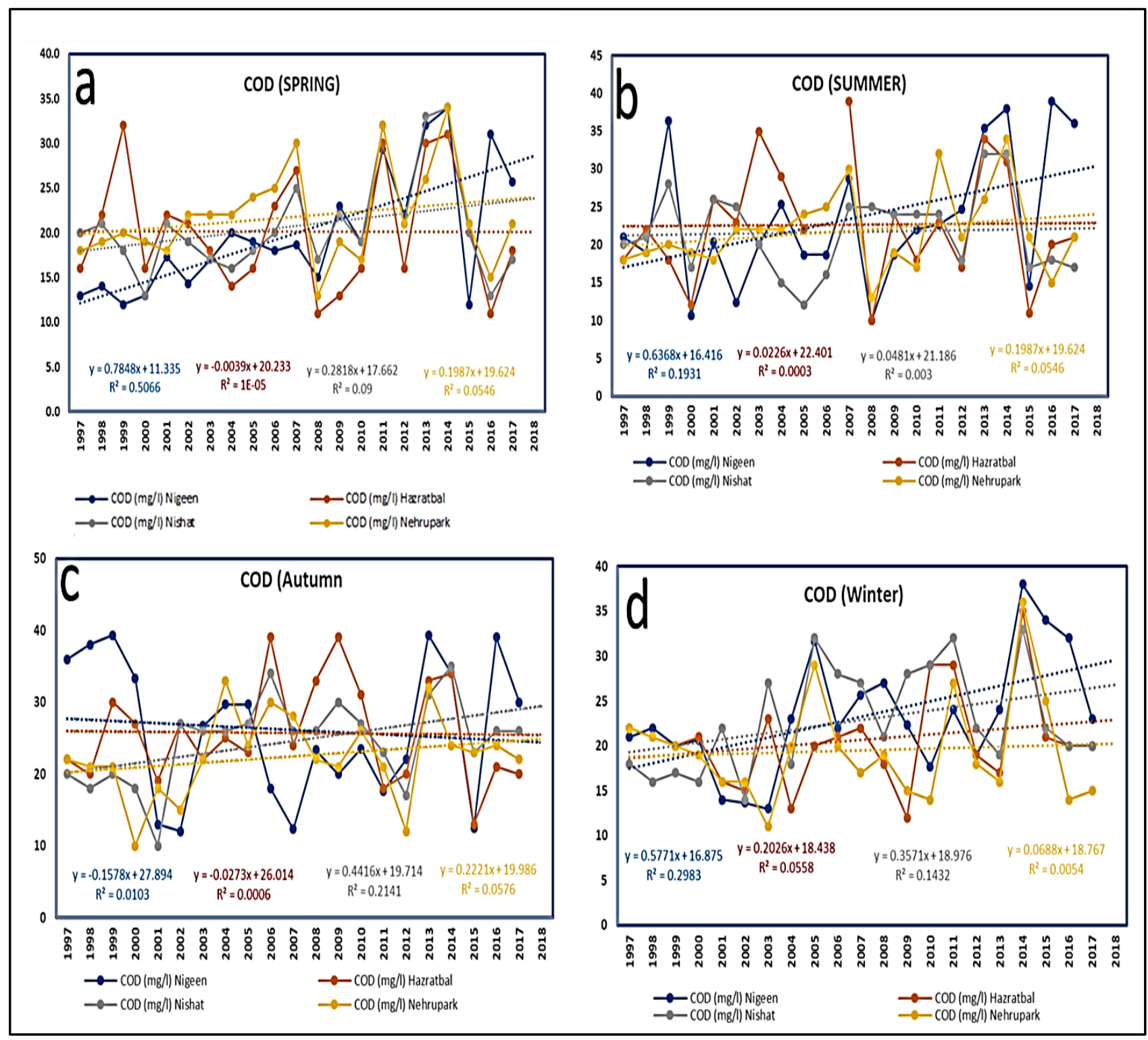

Fig. 5. showing decadal variation of COD in Dal Lake from 1997-2018 (a) spring (b) summer (c) autumn and (d) winter

$\mathrm{NO}_{3}-\mathrm{N}$ : Average annual values of $\mathrm{NO}_{3}{ }^{-} \mathrm{N}$ ranged from 0.33 $\mathrm{mg} / \mathrm{l}$ (1997) to $0.67 \mathrm{mg} / \mathrm{l}$ (2018) from last two decades. In the spring season the decadal trendlines of $\mathrm{NO}_{3}{ }^{-} \mathrm{N}$ have increased in all basins of lake. Maximum increasing trend line was found for Nehru park basin $(y=0.0115 x+0.4429$, $\mathrm{R}^{2}=0.2106$ ) (Fig. 6a)and lower increasing trendline was found for Hazratbal basin $(\mathrm{y}=0.0007 \mathrm{x}+0.5719$, $\mathrm{R}^{2}=0.0009$ ). $\mathrm{NO}_{3}{ }^{-} \mathrm{N}$ graph clearly indicates that from 1997 $\mathrm{NO}_{3}{ }^{-} \mathrm{N}$ has increased upto $70 \%$ mostly in Nishat basin. In the summer season the trendlines of $\mathrm{NO}_{3}{ }^{-} \mathrm{N}$ have increased in all basins of lake (Fig.6b) Maximum increasing trend line was found for Nigeen basin $(\mathrm{y}=0.022 \mathrm{x}+0.3582$, $\mathrm{R}^{2}=0.2573$ ) and lower trendline was found for Nishat basin $\left(y=0.0017 x+0.6154, \quad R^{2}=0.0027\right) . \quad \mathrm{NO}_{3}-\mathrm{N}$ graph in summer season clearly indicates that from $1997 \mathrm{NO}_{3}{ }^{-} \mathrm{N}$ has increased upto a percentage of 150 mostly in Nigeen basin. In the autumn season (Fig. 6c)the decadal trendlines of $\mathrm{NO}_{3}$ $\mathrm{N}$ have increased in all basins of lake except Nishat basin.
Maximum increasing trend line was found for Nigeen basin $\left(\mathrm{y}=-0.0065 \mathrm{x}+0.5914, \quad \mathrm{R}^{2}=0.0542\right)$ and decreasing trendline was found for Nishat basin $(\mathrm{y}=-0.0153 \mathrm{x}+0.7549$, $\left.\mathrm{R}^{2}=0.0941\right) . \quad \mathrm{NO}_{3}{ }^{-} \mathrm{N}$ graph in Autumn season clearly indicates that from $1997 \mathrm{NO}_{3}{ }^{-} \mathrm{N}$ has increased upto $250 \%$. In the winter season the decadal trendlines of $\mathrm{NO}_{3}{ }^{-} \mathrm{N}$ have increased in all the basins (Fig. 6d) particularly in Nishat basins of lake. Maximum increasing trend line was found for Nishat basin $\left(\mathrm{y}=-0.0158 \mathrm{x}+0.7581, \mathrm{R}^{2}=0.151\right)$ and lower trendline was found for Nigeen basin $(\mathrm{y}=0.0098 \mathrm{x}+0.6086$, $\left.\mathrm{R}^{2}=0.0968\right) . \mathrm{NO}_{3}{ }^{-} \mathrm{N}$ graph in winter season clearly indicates that from $1997 \mathrm{NO}_{3}{ }^{-} \mathrm{N}$ has increased in all basins of lake upto $120 \%$.Overall average annual decadal values of $\mathrm{NO}_{3}{ }^{-} \mathrm{N}$ from 1997 to 2018 shows trend as $\left(\mathrm{y}=0.0076 \mathrm{x}+0.4741, \mathrm{R}^{2}\right.$ $=0.1777$ ) indicating that the $\mathrm{NO}_{3}{ }^{-} \mathrm{N}$ will further increase to $0.63 \mathrm{mg} / \mathrm{l}$ in 2020, $0.66 \mathrm{mg} / \mathrm{l}$ in 2025 and $0.70 \mathrm{mg} / \mathrm{l}$ in 2030(Fig.

9d). 


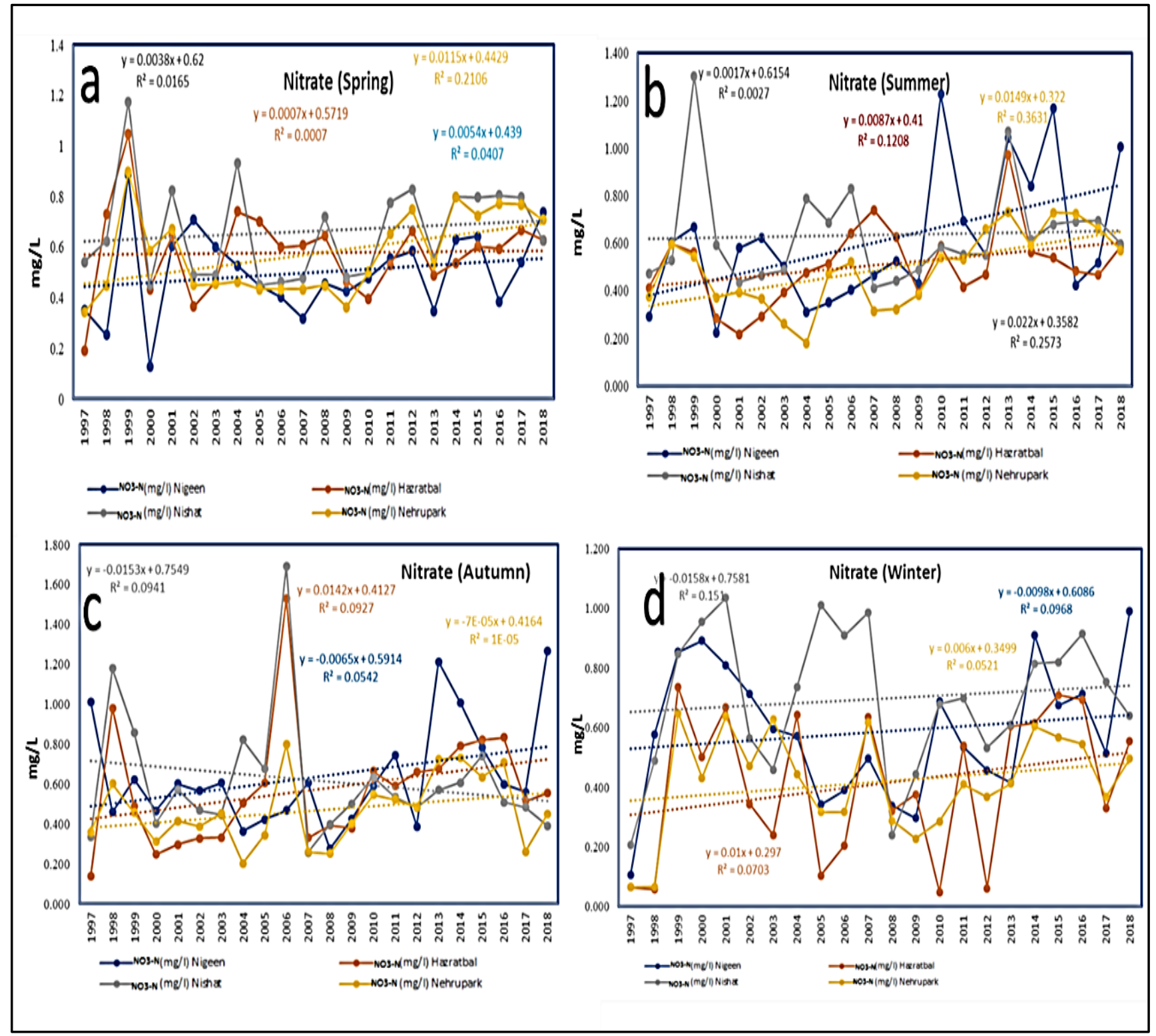

Fig. 6. showing decadal variation of $\mathrm{NO}_{3}-\mathrm{N}$ in DalLake from 1997-2018 (a) spring (b) summer (c)autumn and(d)winter

Total phosphorus (TP): Average annual values of total phosphorus ranged from $0.23 \mathrm{mg} / \mathrm{l}$ (1997) to $0.45 \mathrm{mg} / \mathrm{l}$ (2018) from last two decades. In the spring season the decadal trendlines of TP have increased in all basins of the lake (Fig. 7a). Maximum increasing trendline was found for Nishat basin $\left(y=0.0145 x+0.251, R^{2}=0.4883\right)$ and lower increasing trend line was found for Nehru park basin ( $\mathrm{y}=$ $\left.0.0062 \mathrm{x}+0.2452, \mathrm{R}^{2}=0.0983\right)$. TP graph in summer season clearly indicates that from 1997TP has increased upto $200 \%$.In the summer season the decadal trendlines of TP have increased in all basins of the lake.Maximum increasing trendline was found for Nigeen basin(Fig. 7b)( $\mathrm{y}=0.012 \mathrm{x}+$ $\left.0.2712, R^{2}=0.2878\right)$ and lower increasing trend line was found for Hazratbal basin $\left(y=-0.0071 x+0.4649, \mathrm{R}^{2}\right.$ $=0.0871)$. TP graph in summer season clearly indicates that from 1997 TP has increased upto 190\%.In the autumn season the decadal trendlines of TP have drastically increased (Fig. 7c)in all basins of the lake. Maximum increasing trend line was found for Nigeenbasin ( $\mathrm{y}=$ $\left.0.0206 x+0.1715, \mathrm{R}^{2}=0.5807\right)$ and lower trendline was found for Nishat basin $\left(\mathrm{y}=0.0023 \mathrm{x}+0.3707, \mathrm{R}^{2}\right.$ $=0.0158)$. TP graph in Autumn season clearly indicates that from 1997 TP has increased upto 150\%. In the winter season the decadal trendlines of TP have increased in all the basins of the lake except Nehru park basin(Fig.7d).Maximum increasing trend line was found for Nishat basin $\left(y=0.0205 x+0.2017, R^{2}=0.4635\right)$. Nehru park showed a decreasing trend line for $\left(\mathrm{y}=-0.0057 \mathrm{x}+0.3616, \mathrm{R}^{2}=\right.$ 0.1325). TP graph in winter season clearlyindicates that from 1997 TP has increased upto 175\%. Overall average annual decadal values ofTP from 1997 to 2018 shows trend as $\left(\mathrm{y}=0.0086 \mathrm{x}+0.2643, \mathrm{R}^{2}=0.4446\right)$ indicating that the TP will further increase to $0.44 \mathrm{mg} / \mathrm{l}$ in $2020,0.48 \mathrm{mg} / \mathrm{l}$ in 2025 and 0.52mg/l in 2030(Fig. 9e). 


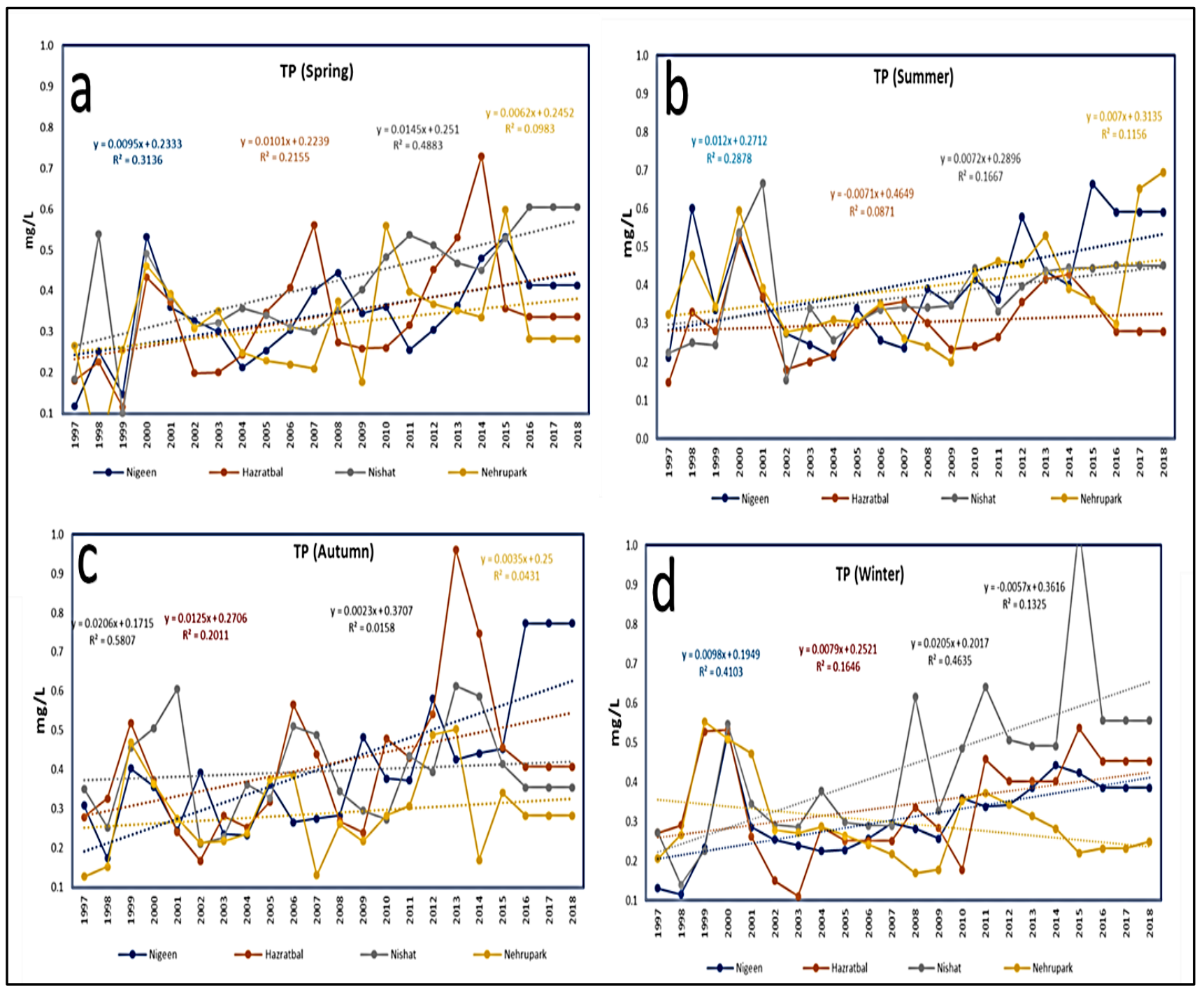

Fig. 7. Showing decadal variation of TP inDal Lake from 1997-2018 (a) spring (b) summer (c) autumn and (d) winter

Transparency: Average annual values of transparency ranged from 1.0 (2018) to $1.6 \mathrm{~m}$ (1997) from last two decades. In the spring season the decadal transparency trendlines have decreased in all basins of the lake except Nishat basin which showed an increasing trend for ( $\mathrm{y}=$ $0.0118 x+0.789$ ) (Fig. 8a). Maximum decreasing trend line was found for Nigeen basin( $y=-0.0373 \mathrm{x}+1.9134$, $\mathrm{R}^{2}=0.2643$ ) and lower trendline was found for Nehru park basin $\left(y=-0.0236 x+2.0457, R^{2}=0.2281\right)$. Nishat basin shows slightlyincreasing trend for $(y=0.0118 x+0.789)$ transparency graph clearly indicates that from 1997 transparency has decreased upto $100 \%$. In the Summer season the decadal transparency trendlines have decreased in all basins of the lake except Nishat basin(Fig. 8b).Maximum decreasing trend line was found for Nigeen basin $(y=-0.0479 x+$ 2.1688, $\mathrm{R}^{2}=0.2799$ ) and lower trendline was found for Nehru park basin $\left(y=-0.0236 x+2.0457, R^{2}=0.2281\right)$. Nishat basin shows slightly increasing trend for $(\mathrm{y}=0.0104 \mathrm{x}+$ 0.8).Transparency graph in summer season clearly indicates that from 1997 transparency has decreased upto 125\%. In the autumn season the decadal transparency trendlines have decreased in all basins of the lake(Fig. 8c)exceptNishat basin. Maximum decreasing trend line was found for Nigeen basin $\left(y=-0.0455 x+2.0143, R^{2}=0.364\right)$ and lower trendline was found for Nehru park basin $(y=-0.0099 x+1.5705$, $\left.\mathrm{R}^{2}=0.364\right)$. Nishat basin shows slightly increasing trend for $(\mathrm{y}=0.0023 \mathrm{x}+0.8171)$ transparency graph in summer season clearly indicates that from 1997 transparency has decreased upto $100 \%$ In the winter season the decadal transparency trendlines have decreased in all basins of the lake except Nishat basin. Maximum decreasing trend line was found for Nigeen basin $\left(\mathrm{y}=-0.0816 \mathrm{x}+2.5519, \mathrm{R}^{2}=\right.$ $0.5517)$ and lower trendline was found for Nehru park basin $\left(\mathrm{y}=-0.0262 \mathrm{x}+1.96, \mathrm{R}^{2}=0.3041\right)$. Nishat basin shows slightly increasing trend(Fig. $8 \mathrm{~d})$ for $(\mathrm{y}=0.0084 \mathrm{x}+0.9548)$ transparency graph in summer season clearly indicates that from 1997 transparency has decreased upto 250\%.Overall average annual decadal values oftransparency from 1997 to 2018 shows trend as $\left(\mathrm{y}=-0.0228 \mathrm{x}+1.6869, \mathrm{R}^{2}=0.4154\right)$ indicating that transparency will further decrease to $1.2 \mathrm{~m}$ in 2020, 1.10m in 2025 and $1.0 \mathrm{~m}$ in 2030(Fig. 9f). 
Forecasting Past and Future Trend of Physio-Chemical Parameters in Dal Lake, Srinagar Kashmir, India using Statistical Analysis and Modelling

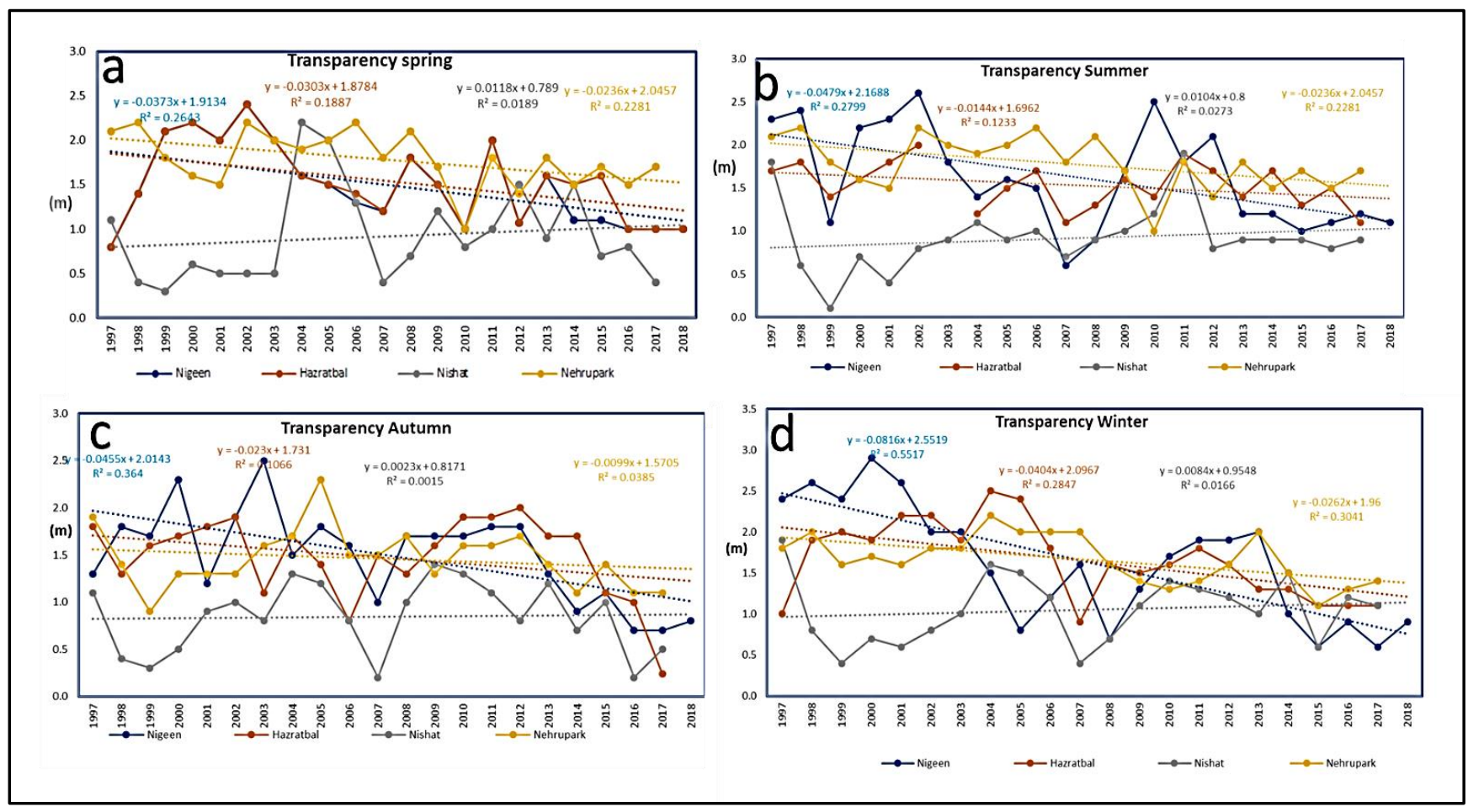

Fig. 8. showing decadal variation of transparency in Dal Lake from 1997-2018 (a) spring (b) summer(c) autumn and (d) winter

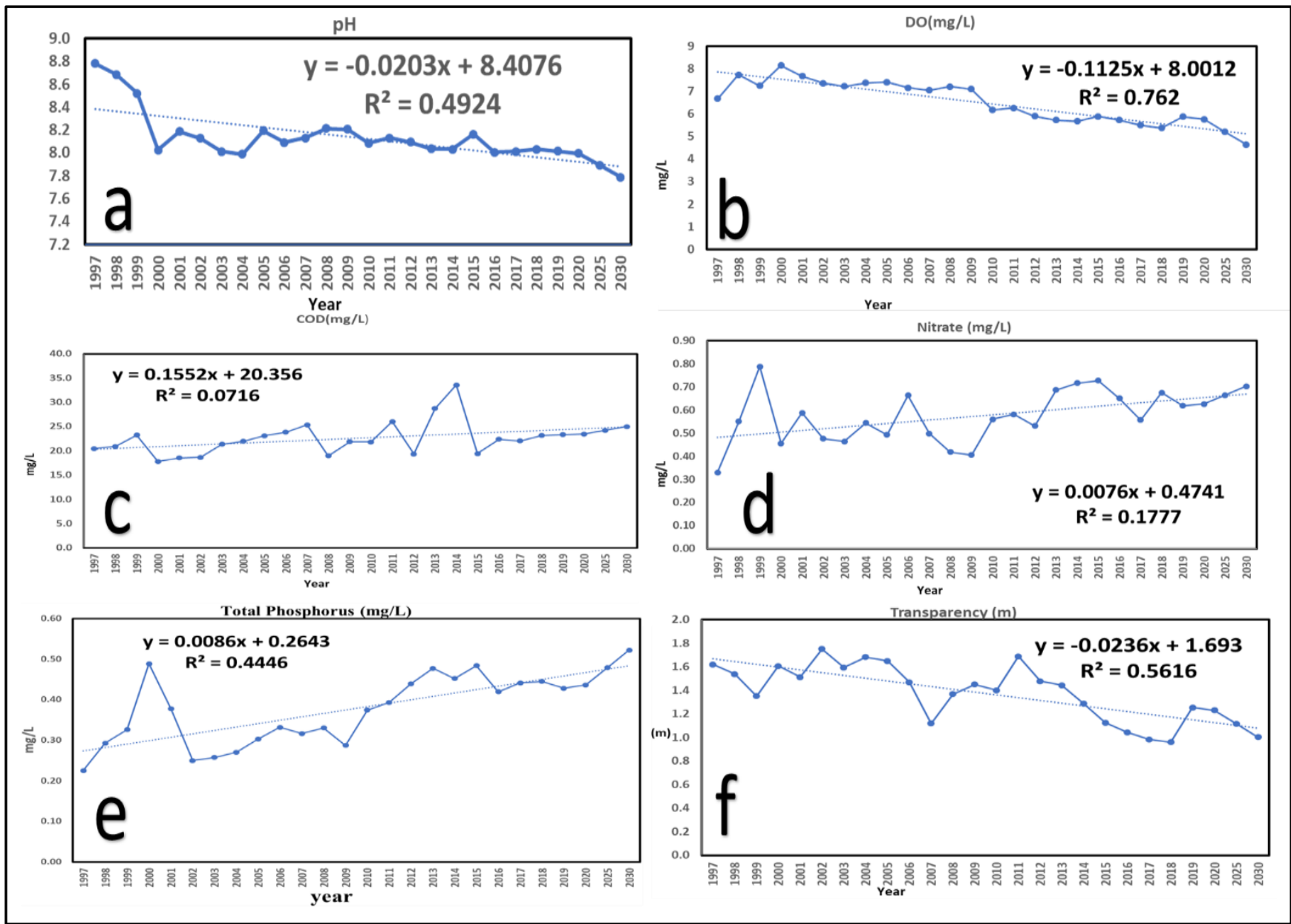

Fig. 9. Showing Overall annual average past and forecasted future trend from 1997-2030 of (a) pH (b) DO (c) COD (d) $\mathrm{NO}_{3}-\mathrm{N}$ (e) TP (f)Transparency. 


\section{CONCLUSION}

From the current results it is concluded that the main reasons for the deterioration of the water quality of Dal Lake are increase in the nutrients from the catchment due to uncontrolled use of fertilizers and pesticides, unplanned urbanization and encroachment, in and around Dal Lake.The physico-chemical analysis shows an increase of most of the water quality parameters particularly $\mathrm{NO}_{3}{ }^{-} \mathrm{N}$, total phosphorus and COD in summer season. Due to the increase of these nutrients, the ecology of the lake is changing and is adversely affecting waterquality therein. As a result of nutrient enrichment, a drop in the dissolved oxygen content has been observed for which artificial lake aeration should be installed to increase the dissolved oxygen levels.Dal Lake serves domestic, agriculture, irrigation,and other commercial sectors (including hotels at boulevard, in around Dal Lake), which have a direct bearing on the water quality of Dal Lake. It is inferred from the study that rate of eutrophication has increased considerably (as depicted by water quality trends of past and future concentration of various water quality parameters) in summer season which can be attributed to high tourist inflow during the season. So, the heavy tourist influx and agricultural activitiesinand around the Dal Lake cause hypereutrophication for which long-term planning and implementation of lake management as strategies may be needed to refine and adapt to improve andpreserve the present-day lake water quality. The present study is the first attempt on future trend analysis and can be used forfuture planning and management of the lake.

\section{REFERENCES}

1. 1.Lehner B, Doll P (2004) Development and validation of a global database of lakes, reservoirs and wetlands. Journal of Hydrology, 296(1-4), pp.1-22

2. Karafistan A, Martin JM, Rixen M, Beckers JM (2002) Space and time distributions of phosphate in the Mediterranean Sea. Deep Sea Research Part I: Oceanographic Research Papers, 49(1), pp.67-82

3. Simeonov V, Stratis JA, Samara C, Zachariadis G, Voutsa D, Anthemidis A, Sofoniou M, Kouimtzis Th (2003) Assessment of the surface water quality in Northern Greece. Water research, 37(17), pp.4119-4124.

4. Zimmerman AR, Canuel EA, (2000) A geochemical record of eutrophication and anoxia in Chesapeake Bay sediments: anthropogenic influence on organic mattercomposition. Marine Chemistry, 69(1-2), pp.117-137.

5. Wetzal RG (2001) Limnology. Lake and River Ecosystems, 3rd edn. ISBN-13:978 012744760

6. Jeelani G, Shah AQ (2006) Geochemical characteristics of water and sediment from the Dal Lake, Kashmir Himalaya: constraints on weathering and anthropogenic activity. Environ Geol 50:12-30

7. Zhu GF, Su YH, Feng Q (2008) The hydro geochemical characteristics and evolution of groundwater and surface water in the Heihe River Basin, northwest China. Hydrogeol J 16:167-182

8. 8.Sheikh JA, Jeelani G, Gavali RS, Shah RA (2014) Weathering and anthropogenicinfluences on the water and sediment chemistry of Wular Lake, Kashmir Himalaya. Environmental earth sciences, 71(6), pp.2837-2846. Wular Lake, Kashmir Himalaya. Environ Earth Sci. doi:10.1007/ s12665-013-2661-z

9. Jeelani G, Shah RA, Hussain A (2014) Hydrogeochemical assessment of groundwater in Kashmir Valley, India. J Earth Syst Sci 123(5):1031-1043

10. Oluduro AO, Adewoye BI (2007) Efficiency of moringa Oleifera Sead extract on the micro flora of surface and ground water. J Plant Sci 6:453-438

11. 11.Trisal CL (1987) Ecology and conservation of Dal Lake, Kashmir. Int J Water Resour Dev 3(1):44-54

12. Singh O, Rai SP, Kumar V, Sharma MK, Choubey VK (2008) Water quality andeutrophication

13. 13.Yaqoob KU, Pandit AK, Wani SA (2008) Comparative physicochemical limnology of three lakes of Kashmir Himalaya. In:
Sengupta M, Dalwani R (eds) Proceedings of Taal 2007: the 12th world lake conference, pp 1922-1927

14. Qadri H, Yousuf AR (2008) Dal Lake ecosystem: conservation strategies and problems. In: Sengupta M, Dalwani R (eds)Proceedings of Taal 2007: the 12th world lake conference, pp 1922-1927

15. Khan JA, Gavali RS, Shouche YS (2012) Exploring present status of Hydrochemistry and Sediment chemistryof Dal Lake, Kashmir and effect of anthropogenic, Disturbances on it. Indian J Innov Dev 1(7)

16. 16.Saleem M, Jeelani G (2017) Geochemical, isotopic and hydrological mass balance approaches to constrain the lake watergroundwater interaction in Dal Lake, Kashmir Valley. Environmental earth sciences, 76(15), p.533.

17. Shuchun Y, Bin X, Deyang K (2010) Chronology and nutrients change in recent sediment of Taihu Lake, Lower Changjiang River Basin, East China. Chin Geogr Sci 20(3):202-208

18. 18.Saini RK, Swain S, Patra A, Khanday GJ, Gupta H, Purushothaman P ,ChakrapaniGJ (2008) Water chemistry of three Himalayan Lakes: Dal (Jammu \& Kashmir), Khajjiar (Himachal Pradesh) and Nainital (Uttarakhand). Ann. rainfall (mm), 655(2648), p.2300.

19. 19.Saleem M, Jeelani G, Shah RA (2015) Hydrogeochemistry of Dal Lake and the potential for present, future management by using facies, ionic ratios, and statistical analysis. Environmental earth sciences, 74(4), pp.3301-3313.

20. 20.Singh R, Sharma VK (1999) Geo environmental appraisal of Mansar and Surinsar Lakes, Udhampur and Jammu districts .Geological Survey of India Records, 131, 19-24.

21. Zutshi DP, Vass KK (1978) Limnological studies on Dal lakechemical features [India]. Indian Journal of Ecology (India).

22. Kanakiya RS, Singh SK, Sharma JN (2014) Determining the water quality index of an urban water body Dal Lake, Kashmir, India. IOSR Journal of Environmental Science, Toxicology and Food Technology, 8(12), pp.64-71.

23. Saleem M, Jeelani G (2016) Anthropogenic induced evolution of chemical quality of water in Dal Lake, Srinagar. Journal of Research \& Development, Vol. 16

24. Saleem M , Jeelani G (2017) Estimation of groundwater inflow to Dal Lake using isotopic mass balance approach. International Symposium on Sustainable Urban Environment

\section{AUTHORS PROFILE}

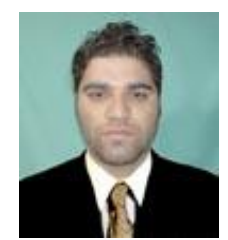

Ishtiyaq Ahmad Rather is a Research schola pursuing PhDfromthe Department of Civil EngineeringNational Institute of Technology Srinagar-India.His research interestsincludes,Hydraulic Engineering,Hydrogeochemistry,Climate changeModelling, Remote Sensing and GIS.

ishtiyaq_civilphd@nitsri.ne

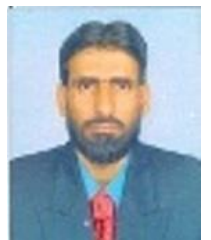

Dr. A.Q DAR, Professor in the Department of Civi Engineering, National institute of Technology Srinagar-India. He is specialized in Hydraulic Engineering, Climate change Modelling, Remote Sensing and GIS.

aqayoom2001@yahoo.com 